2148-VIII ( 2148-08 ) vid 19.10.1973 r. URL: http://zakon3.rada.gov.ua/laws/show/995_043. [in Ukr.]

9. Konventsiya pro zakhyst prav lyudyny i osnovopolozhnykh svobod [Convention for the Protection of Human Rights and Fundamental Freedoms]. Rada Yevropy: Konventsiya, Mizhnarodnyy dokument vid 04.11.1950 r. Ofitsiynyy visnyk Ukrayiny. 16.04 .1998 r. № 13 / 23.08.2006. № 32. S. 270. URL: https://zakon.rada.gov.ua/laws/show/995 004/ed19900101. [in Ukr.]

10. Rukovodstvo OBSE po polytseyskoy deyatel'nosty na osnove operatyvnykh dannykh y ynformatsyy [OSCE Police Guide on the basis of operational data and information]. DTNU/OSVPD, yzdanye 13, Vena, 2017. 108 s. [in Russ.]

11. Dovidnyk kerivnyka politsiyi - politseys'ka diyal'nist', kerovana rozviduval'noyu anali-tykoyu [Directory of the police chief - police activity guided by intelligence analytics] / ILP : navchal'nyy posibnyk / Korystin O.YE., Peftiyev D.O., Pen'kov S.V., Nekrasov V.A.; za zah. red. Verbens'koho M.H. Kyyiv : «Vydavnytstvo Lyudmyla», 2019. 120 s. [in Ukr.]

12. Pro zakhyst personal'nykh danykh [On protection of personal data]: Zakon Ukrayiny vid 01.06.2010 № 2297-VI. Vidomosti Verkhovnoyi Rady Ukrayiny. 2010. № 34. St. 481. [in Ukr.]

\title{
Summary
}

In the article the basic national and international norms and principles are examined, which are used by police officers in conducting intelligence-led policing to ensure the standards of human and citizen rights and freedoms. It is noted that criminal analysis, being a specific type of information and analytical activity of the police, forms a new sphere of interaction of police officers with the society on the basis of analytical intelligence, which has a number of features, including in matters of respect for fundamental rights and freedoms of man and citizen. It is concluded that the violation of human rights and freedoms in the model of police intelligence-led intelligence is counterproductive and ineffective in the long run, since it undermines citizens' trust in the police, so it is important that different operational methods of collecting information that interfere with human rights should have effective scrutiny by the judicial or other independent bodies to which police officers seek prior permission to carry out these activities.

Keywords: human and citizen's rights and freedoms, criminal analysis, analytical intelligence.

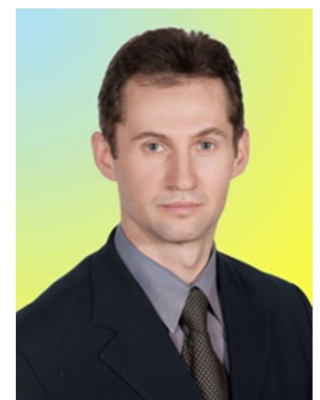

\author{
Dmytro \\ KAZNACHEYEV ${ }^{\odot}$ \\ Ph.D, Ass. Prof.
}
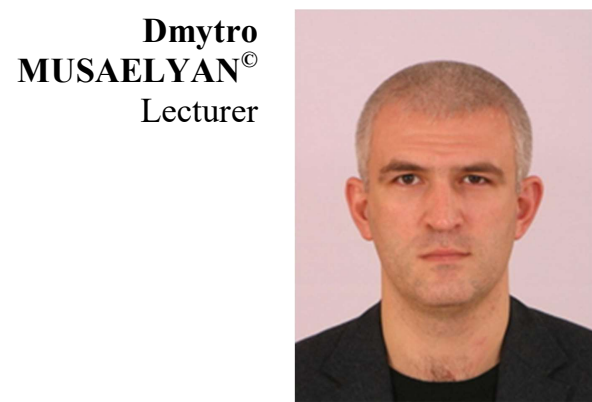

(Dnipropetrovsk State University of Internal Affairs)

\section{LEGAL REQUIREMENTS FOR THE PURCHASE, STORAGE AND WEARING OF WEAPONS IN UKRAINE}

Дмитро Казначесв, Дмитро Мусаелян. ПРАВОВІ ВИМОГИ ЩОДО ПРИДБАННЯ, ЗБЕРІГАННЯ ТА НОСІННЯ ЗБРОЇ В УКРАЇНІ. Здійснено аналіз відомчих нормативноправових актів, що регламентують порядок придбання, зберігання та продажу вогнепальної зброї громадянам України, які ліцензійні вимоги існують в Україні щодо покупки, зберігання та продажу вогнепальної зброї фізичним особам і організаціям, відповідність їх сучасним реаліям. Проводиться ретроспективний аналіз щодо навчання вогневої підготовки кандидатів на придбання вогнепальної зброї за часів Радянського Союзу та в сучасній Україні. Розглядаються правові вимоги, в тому числі вікові терміни і параметри навчання, володіння та користування зброєю, ситуації, права, умови та підстави за яких громадяни України можуть придбати у власне користування нарізну вогнепальну зброю. Особлива увага приділена проведенню спеціального навчання навичкам

(C) Kaznacheyev D., 2019

ORCID iD: https://orcid.org/0000-0001-5193-7176

k_tsp@dduvs.in.ua

(C) Musaelyan D., 2019

k_tsp@dduvs.in.ua 
поводження з вогнепальною зброєю осіб які бажають придбати ії у власне користування, його тематична наповненість та передбачене навантаження. Також в статті розглядається порядок проведення попередньої перевірки дозвільними центрами МВС України, щодо дотримання громадянами України вимог передбачених законодавством. Надається стисла характеристика кваліфікаційних вимог до самої зброї, яка може бути придбана громадянами України у власне користування. Аналізується сам порядок і процедура купівлі, продажу та обліку нарізної вогнепальної зброї громадянами України та вносяться пропозиції щодо їх покращення та приведення у відповідність сучасним реаліям.

Ключові слова: зброя, обіг зброї, права громадян на носіння зброї, зберігання та перевезення зброї самозахисту, правове регулювання, лічензійні вимоги обігу зброї.

Problem statement. Currently in Ukraine the legal requirements for the purchase, storage and sale of weapons are regulated by the order of the Ministry of Internal Affairs of Ukraine № 622 of 21.08.1998 "On approval of the Instruction on the procedure for the manufacture, purchase, storage, accounting, transportation and use of fire, pneumatic, cold and blade weapons, devices of domestic production for shooting cartridges equipped with non-lethal rubber or similar metallic projectiles and cartridges, as well as ammunition for weapons, major parts to weapons and explosive materials »[1]. Over the past 20 years, there were done more than ten changes and additions in this Order, the most recent changes were made in 2018, but all of them have only increased the control of the Ministry of Internal Affairs and changed the name of the relevant controlling bodies. To date, this instruction does not meet the modern requirements and wishes of the citizens of Ukraine, because all requirements for the purchase and trade of weapons have remained virtually unchanged since of the Soviet Union.

Analysis of publications that started solving this problem. The proposed topic is in the constant circle of scientific search, as it gives an opportunity to analyze the previous experience of the legal requirements for the acquisition, storage and carrying of weapons in Ukraine, identify any shortcomings and create the most effective legislation to further regulate the circulation of weapons in Ukraine.

The article's objective is to determine the legal requirements for the acquisition, storage and carrying of weapons in Ukraine.

Basic content. In modern Ukraine, are needed other requirements, and first of all not only for the purchase of weapons, but also for training citizens to use them. In the former Soviet Union, training in shooting and usage of weapons was conducted from the 4th year of secondary school. But was very difficult to buy weapons in Soviet state, because there was not need most citizens owners of firearms. Any citizen of the former Soviet Union could give life for the state with a weapon in his hands, since the age of 18, being a soldier of the Soviet Army. But they could acquire weapons for their own use only as a member of a hunting collective with a bunch of other requirements for acquisition, especially rifled weapons was only purchased at the age of 25. But, imagine, such requirements have remained in modern Ukraine!

At present, an absurd situation has arisen in our country, at a time when there is a war in the country, when many young men give their lives for the state, they have no right to buy their own rifles unless they are 25 years old. A citizen may be the hero of his country, may have the skills to use any weapon, be an officer and a respectable commander, but to purchase a weapon, if he is not 25 years old, he can not - prohibited by the requirements of the Order of the Ministry of Internal Affairs of Ukraine № 622 of 21.08 .1998 (!). He must also provide a certificate of training in shooting, which is nonsense in itself. And the certificate is only a formality, and such formal training does not give lasting skills to use weapons to ordinary citizens. This "training" is conducted at couple lessons and gives only introductory theory of using weapons, and in most cases it remains only on paper. Some more requirements for the acquisition of weapons in modern Ukraine are unclear, such as certificates of mental status and drug dependence from any category of citizens, it is understandable if the person is not related to the armed forces, the Ministry of Internal Affairs, or other paramilitary structure, but why who already serves the state?! Changes in the rules of purchase of weapons and, first of all, in training to use weapons, why you need to study not one or two times, but for several months, like driving a car, are required to teach people the skills of handling weapons, legal rules, especially what is strictly prohibited when handling weapons, only then get the right to buy weapons. If a citizen violates the rules for the use and storage of weapons, he must pass an exam or be deprived of this right and certificate. But if a citizen has never violated legal requirements and wants to buy more weapons, then each time he must collect a bunch of information, which in itself is a prerequisite for creating bureaucracy and bribery. Why is it necessary to obtain a certificate from the Ministry of Internal Affairs Information Center for the absence of a criminal conviction from a person wishing to purchase a 
weapon, if this information is not a secret for any employee of the Ministry of Internal Affairs? Of course, you need to know about the medical condition of a citizen who wants to buy a weapon. But why not open the accessibility of employees of permitting service of the Ministry of Internal Affairs to the account of people who are drug addicted or mentally disabled persons, and in case of registration to withdraw the weapon from such owner with forced sale? To oblige the relevant authorities to promptly notify the permitting servise of changes in a person's life, under which he or she may be deprived of the right to use a weapon. But if the person who has been trained has experience in using a weapon, you should be able to buy it freely, without collecting a bunch of information every time in a large bureaucratic system. The purchase must be made only after presentation of the certificate of the right to use the weapon, but the training should be not one day but few months, with the exam being passed before the commission of experienced employees of the permitting service (by analogy with the driving license exam). The exam should include questions not only about knowledge and ability to use a weapon, but also knowledge of regulations and emergency medical care. Another interesting question is the reconsideration of weapons every three years or less, it is a meaningless bureaucracy and the development of bribery! If there is a suspicion of misuse or possession of a weapon, the permitting services employee has the right to check compliance with the legal requirements. But constant recalculation gives nothing interesting except for the large amount ofunnecessary work and time spent because the experienced user knows what to do with the weapon before being check by the law enforcement agencies. It would be better to check the conditions of storage of the weapon more often, as the presence of safes at gun owners remains in most cases on paper.

Requirements for the acquisition of weapons need to be changed not only in the field of age restrictions, training periods and document collection, but also in the qualification requirements for the weapon itself, for example: to which class should small arms be assigned?

Requirements for the acquisition of small-caliber (rimfire) weapons the same as for the purchase of weapons of the fiftieth caliber, from the age of 25 , but its impressive strength is the smallest, with it begin to learn to shoot students. In my opinion, rimfire rifles can be allowed to buy as well as shotgun. This is an example, but it is possible to develop a classification of weapons according to striking features, including range and deadly force. Currently, many new modern calibers that remain small in diameter can shoot very far. Even air rifles by their characteristics are not inferior to rifles of calibers 221r or 17HMR.

Returning to age-old restrictions on the purchase of weapons, there is no difference in what class of weapons a citizen wants to buy if the lethal force of smooth-bore weapons can be much greater than that of rifled arms. Why does a citizen have the right to purchase a shotgun from 21 years old, a rifle from 25 years old, if the age of majority is from 18 years old and at the same time, from the age of 18 , a citizen can serve to a power with arms in his hands. This age difference in the acquisition of weapons was in the USSR for another reason, namely: there was general military service, and by the year 21 , the vast majority of men had served in the army and, accordingly, gained experience working with weapons, and by 25 years to prove themselves as a reliable supporter of the "party and government", which will not use arms against the communist state. Now there are no such problems. Therefore, I see no reason to do a difference in age when buying weapons; all we need to do is teach citizens how to use it legally.

A separate issue is the authorization to purchase "traumatic weapons," (pistols and revolvers for shooting rubber bullets of traumatic action) - another very bureaucratic procedure that only contributes to the development of bribery. The circulation and procedure of issuing permits for traumatic weapons is governed by the following normative legal acts: Order of the Ministry of Internal Affairs of Ukraine of August 21, 1998No. 622 "On Approval of the Instruction on the Order of..." , registered with the Ministry of Justice of Ukraine on October 11, 2000 under No. 696/4917 "On approval of the Provisional Instruction on the procedure for the purchase, storage, accounting, use and use of domestic production devices for shooting cartridges equipped with rubber or similar nonlethal projectile shells, and the said cartridges, by court employees, law enforcement agencies and their close relatives, as well as by persons involved in criminal proceedings "[2]. Why this order is still considered "for official use", if this secret is freely available on the Internet. But the main thing is that Order \# 379 identified a separate category of citizens, called the "special category", who is allowed to purchase traumatic weapons, what is a direct violation of the Constitution of Ukraine, which made all citizens equal, in any case, "special category of citizens" should not be. In my article "The Legal Basics of the Self-Defense Weapons Circulation in Modern Ukraine" I wrote that the requirements for "traumatic" weapons should be changed. Also, the absence of any restrictions on the barrel of a traumatic weapon makes it virtually a smooth-bore weapon with the impossibility of 
controlling the charges used. In fact, the so-called "traumatic" weapons are smooth-bore, shortbarreled and firearms, because the rigidity of the rubber bullets and the power of such bullets are difficult to control, and with such weapons it is possible to shoot lead bullets or balls. The point of having a traumatic weapon is to do less harm to the victim than when firing a military weapon. But in our case, when most people reinforce bullets in any way, traumatic weapons are just an opportunity to manipulate citizens' desire to buy short-barreled firearms. In continuation of the conversation about short-barreled weapons, we have a separate category of citizens who own combat pistols - these are the people who received award weapons. Among them are real heroes who have been awarded for their feats of war, but there are also many who have found the opportunity to win such rewards through personal connections, often repeatedly. Why this question? Weapons, received as a reward, can be carried with you for self-defense without constant re-registration; the permit issuing service is not allowed to seize it until the owner dies. Let's also change this issue, because again it is a "special category of citizens". Either this award stay at home with the right to wear only in military or police uniforms, or it is necessary to provide citizens with equal rights guaranteed by Article 41 of the Constitution of Ukraine. [4]

There is another interesting question about buying a weapon - it is a permit to buy weapons for businesses. Nowadays only a limited numbers sport-education enterprises can purchase firearms, but not security companies. This leads to the fact that the heads of security companies draw up documents on weapons for their employees as private individuals and re-register them in case of dismissal. As a result, control over the availability of weapons by employees of such an enterprise is significantly complicated. This preserves the monopoly of the Ministry of Internal Affairs on security companies with the ability to work with military weapons. It would be better to develop conditions for the acquisition of weapons by enterprises with a mandatory weapons warehouse, which is constantly monitored by the relevant department of the Ministry of Internal Affairs. Also determine the following conditions: the minimum required number of employees of the enterprise, the minimum required number of years of work of the company in this profile, requirements for the manager (work experience), requirements for employees who will be entitled to work with weapons. All these issues must be under the strict control of the Interior Ministry. Expand the number of working shooting galleries and training ranges that have the right to teach people the skills and culture of using weapons. If the citizens of Ukraine get more opportunities to learn how to shoot and understand how the legal requirements work, they will be more responsible for the acquisition and storage of weapons. It is difficult to control the carrying and storage of weapons by citizens, but only because the personnel issuing the permits work more to collect a pile of papers than to check these issues and prevent offenses in the circulation of non-military weapons. It is much easier to inspect trading companies with a permit to sell weapons that are interested in compliance rules, so as not to lose that right. There is another small issue in the arms trade, it is the trade in blade weapons. Each trading company must sell a knife with a certificate from an expert center that the knife is not a cold weapon, but most of these products are sold in disassembled condition, because after the sale only the buyer is responsible for it. The knife is defined as a cold weapon should be with a number that the seller must record in any weapons permit, but there is no clear description of knives, as there is no understanding of how to control, if possible, to have several knives with the same number on the blade. It is necessary to change the signs of cold steel or to exclude this concept from the permitting service, since an ax is not considered a weapon, but can be more dangerous than any knife. In my opinion, the concept of "cold weapons" can remain only as a legal term in the qualification of criminal offenses and crimes. There are many more issues related to the storage of weapons, depending on the number of units available to the owner, especially when it is a collection of historical weapons, but collectors and gun lovers are law abiding citizens and respect the existing requirements of the law.

Conclusions. Most people are interested in the requirements for carrying and transporting weapons, which also need updating. For example, are people most often asked whether it is legal or not to carry a cartridge in a chamber? What is the responsibility for the offense and how is it checked? The fact is that there is no criminal liability for such an offense, and it is not required. so there's no point in checking, this is only a prerequisite for abuse of power by the police. World experience shows that carrying a cartridge in the chamber is a desirable and even a necessary condition for the use of self-defense weapons, so in the world, and develop many new models of weapons with reliable automatic fuses. But the culture of handling weapons is that the experienced user will not leave the cartridge in the chamber unnecessarily, and don't leave the weapon unattended. I would like to ask the person who wrote this provision and how to distinguish a revolver type weapon? The revolvers do not have a separate chamber and sometimes a fuse. Whether or not to leave a 
cartridge in the chamber when carrying a weapon is another problem that needs to be eliminated when developing new requirements for carrying and storing weapons. It is much more important to pay attention to the transportation of weapons in cars, especially when the owners are leaving them there. Responsibility for this should be increased, since weapons left unattended in a car can be easy prey for car thieves. The owner must not leave the weapon in the car unattended. All these issues must be taken into account when writing the law on weapons.

\section{References}

1.Про затвердження Інструкції про порядок виготовлення, придбання, зберігання, обліку, перевезення та використання вогнепальної, пневматичної, холодної і охолощеної зброї, пристроїв вітчизняного виробництва для відстрілу патронів, споряджених гумовими чи аналогічними за своїми властивостями метальними снарядами несмертельної дії, та патронів до них, а також боєприпасів до зброї, основних частин зброї та вибухових матеріалів: Наказ МВС України № 622 від 21.08.1998 року / Офіційний вісник України: офіційне видання від 05.11.1998. № 42. Стор. 107. Ст. 1574.

2.Про затвердження Тимчасової Інструкції про порядок придбання, зберігання, обліку, використання та застосування пристроїв вітчизняного виробництва для відстрілу патронів, споряджених гумовими чи аналогічними за своїми властивостями метальними снарядами несмертельної дії, та зазначених патронів працівниками суду, правоохоронних органів та їх близькими родичами, а також особами, які беруть участь у кримінальному судочинстві: Наказ МВС України №379 від 13.06.2000 р., зареєстровано у Міністерстві юстиції України 11.10.2000 р. за № 696/4917.

3. Про право власності на окремі види майна: постанова Верховної Ради України № 2471ХІІ від 17.06.1992 p. URL https://zakon.rada.gov.ua/laws/show/2471-12.

4.Конституція України. Відомості Верховної Ради Украӥни, 1996, № 30, ст. 141). URL: https://zakon.rada.gov.ua/laws/show/254\%D0\%BA/96-\%D0\%B2\%D1\%80.

5.Кримінальний Кодекс України. Відомості Верховної Ради Украӥни, 2001, № 25-26, ст.131). URL: https://zakon.rada.gov.ua/laws/show/2341-14.

Received to editorial office 04.12.2019

1. Pro zatverdzhennya Instruktsiyi pro poryadok vyhotovlennya, prydbannya, zberihannya, obliku, perevezennya ta vykorystannya vohnepal'noyi, pnevmatychnoyi, kholodnoyi i okholoshchenoyi zbroyi, prystroyiv vitchyznyanoho vyrobnytstva dlya vidstrilu patroniv, sporyadzhenykh humovymy chy analohichnymy za svoyimy vlastyvostyamy metal'nymy snaryadamy nesmertel'noyi diyi, ta patroniv do nykh, a takozh boyeprypasiv do zbroyi, osnovnykh chastyn zbroyi ta vybukhovykh materialiv [On approval of the Instruction on the procedure for the manufacture, purchase, storage, accounting, transportation and use of firearms, pneumatic, cold and chilled weapons, devices of domestic production for shooting cartridges equipped with rubber or similar in their properties metallic shells, non-dimensional projectiles, as well as ammunition for weapons, major weapons and explosive materials]: Nakaz MVS Ukrayiny № 622 vid 21.08.1998 roku / Ofitsiynyy visnyk Ukrayiny: ofitsiyne vydannya vid 05.11.1998. № 42. Stor. 107. St. 1574. [in Ukr.]

2. Pro zatverdzhennya Tymchasovoyi Instruktsiyi pro poryadok prydbannya, zberihannya, obliku, vykorystannya ta zastosuvannya prystroyiv vitchyznyanoho vyrobnytstva dlya vidstrilu patroniv, sporyadzhenykh humovymy chy analohichnymy za svoyimy vlastyvostyamy metal'nymy snaryadamy nesmertel'noyi diyi, ta zaznachenykh patroniv pratsivnykamy sudu, pravookhoronnykh orhaniv ta yikh blyz'kymy rodychamy, a takozh osobamy, yaki berut' uchast' u kryminal'nomu sudochynstvi [On approval of the Provisional Instruction on the procedure for the acquisition, storage, accounting, use and use of devices of domestic production for shooting cartridges equipped with rubber or similar in their properties non-lethal metallic shells, and the said cartridges by court staff, law enforcement agencies and relatives also to persons involved in criminal proceedings]: Nakaz MVS Ukrayiny №379 vid 13.06.2000 r., zareyestrovano u Ministerstvi yustytsiyi Ukrayiny 11.10.2000 r. za № 696/4917. [in Ukr.]

3. Pro pravo vlasnosti na okremi vydy mayna [On the ownership of certain types of property]: Postanova Verkhovnoyi Rady Ukrayiny № 2471-XII vid 17.06.1992 r. URL https://zakon.rada.gov.ua/laws/show/2471-12. [in Ukr.]

4. Konstytutsiya Ukrayiny [Constitution of Ukraine]. Vidomosti Verkhovnoyi Rady Ukrayiny, 1996, № 30, st. 141). URL: https://zakon.rada.gov.ua/laws/show/254\%D0\%BA/96-\%D0\%B2\%D1\%80. [in Ukr.]

5. Kryminal'nyy Kodeks Ukrayiny [Criminal Code of Ukraine]. Vidomosti Verkhovnoyi Rady Ukrayiny, 2001, № 25-26, st.131). URL: https://zakon.rada.gov.ua/laws/show/2341-14. [in Ukr.]

\section{Summary}

The article clarifies what licensing requirements exist in Ukraine for the purchase, storage and sale of firearms to citizens and organizations, examines the legal requirements, including the age and parameters of training, possession and use of weapons, rights and conditions for the acquisition of weapons.

At the same time, the law regulates the concept of civilian weapons that is available for purchase and which can be used as a weapon of self-defense within the framework of the necessary defense in accordance with Art. 36 of the Criminal Code of Ukraine. It is concluded that today in Ukraine, in order to legalize the free circulation of weapons for the purpose of self-defense, it is necessary to fulfill a number of requirements: definition and observance of the boundaries of necessary defense; training, obtaining permission to purchase weapons only after passing the exam; definition of the category of citizens who can not have such a right; to provide high-quality and timely state control over the circulation of weapons

Keywords: weapons, arms trade, ownership rights of citizens, storage and transportation of selfdefenses firearm, legal regulation, licensing requirements arms traffic. 